\title{
Pengaruh inkuiri terbimbing terhadap kemampuan mengidentifikasi sumber energi di sekitar manusia dan kemandirian belajar IPA
}

\author{
Dindya Sisca Prahenti, Rusijono Rusijono, Andi Mariono \\ Pascasarjana, Universitas Negeri Surabaya. \\ J1. Lidah Wetan, Lakarsantri, Surabaya, Jawa Timur 60213, Indonesia. \\ dindya.18001@mhs.unesa.ac.id \\ * Corresponding Author
}

\section{ARTICLE INFO}

\section{Article History}

Received:

27 August 2020;

Revised:

15 September 2020;

Accepted:

2 October 2020

Keywords

Inkuiri terbimbing;

Kemandirian belajar;

Kemampuan

mengidentifikasi;

Ability to identify;

Guided inquiry;

Homeschooling;

Self-regulated learning

\begin{abstract}
Penelitian ini bertujuan untuk mengetahui pengaruh model inkuiri terbimbing terhadap kemandirian belajar siswa dan kemampuan mengidentifikasi sumbersumber energi yang ada di lingkungan sekitar manusia pada siswa kelas 2 Sekolah Dasar di Sinergia Worldwide Education Surabaya. Subjek penelitian ini adalah siswa kelas 2 SD di Sinergia Worldwide Education Surabaya yang terbagi ke dalam dua kelas, yaitu kelompok kontrol dan kelompok eksperimen. Waktu pelaksanaan penelitian adalah pada bulan Maret hingga April 2020, yaitu pada semester genap. Metode penelitian yang digunakan adalah Mann Whitney U-test dan Wilcoxon Sign-Test. Model Mann Whitney U-test dan Wilcoxon Sign-Test bertujuan untuk membandingkan hasil dari perolehan nilai pretest dan posttest yang didapatkan antar dua kelompok, serta untuk melakukan uji validasi instrumen penelitian yang digunakan. Hasil dari penelitian ini menunjukkan terdapat pengaruh model inkuiri terbimbing terhadap kemandirian siswa, karena model inkuiri terbimbing lebih efektif dalam meningkatkan kemandirian belajar siswa, serta terdapat pengaruh model inkuiri terbimbing terhadap kemampuan siswa dalam mengidentifikasi sumber-sumber energi yang ada di sekitar manusia, karena dengan menerapkan model inkuiri terbimbing siswa dapat lebih aktif dalam menjawab pertanyaan-pertanyaan materi.
\end{abstract}

This study aims to determine the effect of the guided inquiry model on student learning independence and the ability to identify energy sources in the environment around humans in grade 2 elementary school students at Sinergia Worldwide Education Surabaya. This study's subjects were students of grade 2 Elementary School at Sinergia Worldwide Education Surabaya, which were divided into two classes, namely the control group and the experimental group. The time of research is from March to April 2020. The research method used is the Mann Whitney U-test and Wilcoxon Sign-Test. The Mann Whitney U-test and Wilcoxon Sign-Test models aim to compare the obtained pretest and post-test scores. The Mann Whitney U-test and Wilcoxon Sign-Test models were also used to test the research instruments' validation. The results of this study indicate that the guided inquiry model has an influence on students' independence because the guided inquiry model is more effective in increasing students' learning independence, and there is an influence of the guided inquiry model on students' ability to identify energy sources around humans, because by applying Guided inquiry model students can be more active in answering material questions.

This is an open access article under the CC-BY-SA license.

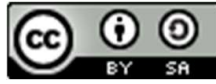




\section{PENDAHULUAN}

Sebagai salah satu tri pusat pendidikan (formal, informal, dan non-formal) dimana terjadi proses pembelajaran di dalamnya, homeschooling yang termasuk di dalam kategori pendidikan nonformal atau pendidikan yang berbasis pada pendekatan dengan orang tua, dalam praktiknya seharihari juga tak luput dari permasalahan, khususnya permasalahan di bidang pendidikan. Dengan siswa di rentang usia tujuh hingga delapan tahun atau kelas 2 sekolah dasar, dengan menggunakan acuan kurikulum Cambridge namun tetap memasukkan mata pelajaran agama, Pendidikan Pancasila dan Kewarganegaraan (PPKN), dan Bahasa Indonesia. Sumber belajar yang dimanfaatkan adalah by utilization yang digunakan untuk memecahkan masalah belajar seperti halaman depan rumah, taman dan kolam renang dengan cara menjelaskan sesuai konteks materi yang sedang di pelajari (Wibowo, 2016). Hal tersebut juga menjadikan homeschooler lebih memahami materi pelajaran IPA yang harus dikuasainya.

Guru disini menggunakan pendekatan pedagogi pada homeschooler (sebutan untuk siswa homeschooling), dengan menerapkan teori belajar behavioristik dan kognitivistik yang mempercayai adanya stimulus dan respon untuk rangsangan proses pembelajaran, serta untuk dukungan peran dari lingkungan sekitar. Keberadaan dari homeschooling sendiri adalah sebuah jawaban atau solusi dari permasalahan belajar yang ada pada masyarakat Indonesia (Ariefianto, 2017). Peserta didik (pebelajar) yang kerap mengikuti keluarga yang bepergian karena dinas dan telah memiliki karir di bidang non-akademis tetap bisa melakukan aktivitas, proses atau pengalaman belajar tanpa terbelenggu peraturan seperti di sekolah formal, yaiut seperti penerapan pakaian seragam dan jadwal belajar yang sudah baku. Teori ini sejalan dengan teori kesemrawutan di era ketidakpastian seperti saat ini (sybernitic concept). Silabus yang digunakan dalam proses pembelajaran adalah Cambridge Primary Curriculum. Silabus Cambridge Primary Curriculum dikhususkan untuk siswa dengan rentang usia 5 hingga 11 tahun yaitu siswa sekolah dasar (Susanti, Murtini, \& Harini, 2018). Inilah hasil dari analisis kebutuhan (need assessment) yang telah peneliti lakukan di lapangan.

Karena dibutuhkannya penelitian untuk pendidikan non-formal seperti halnya sekolah formal, pendidikan non-formal memiliki standarisasi dalam proses kegiatan belajar mengajar. Acuan pembelajaran terjabar pada RPP (Rencana Pelaksanaan Pembelajaran) yang mana hal tersebut adalah bagian dari perangkat pembelajaran yang akan dikaji dalam penelitian kali ini. Desain Kurikulum atau pembelajaran menjadi hal yang krusial dan mendasar bagi penyelenggaraan pendidikan di Indonesia, sehingga guru diwajibkan untuk memahami dan juga mengimplementasikan isi dari kurikulum tersebut. Perangkat pembelajaran yang bersifat subyek akademik juga tak luput dari pengamatan peneliti, karena hal tersebut berkaitan langsung dengan capaian kompetensi bagi para peserta didik. Di dalam kegiatan belajar mengajar guna mencapai standar kompetensi lulusan tentunya mengalami sebuah proses pembelajaran antara guru dan siswa, untuk itu perlunya diteliti terkait dengan pengembangan perangkat pembelajaran yang digunakan di homeschooling, mengingat terdapat perbedaan antara homeschooling dan sekolah formal. Permasalahan kedua adalah peneliti melihat dengan berjalannya metode konvensional oleh para tutor sebelumnya kepada para siswa homeschooling, menjadi pertanyaan terkait penilaian atau evaluasi untuk indikator tertentu, contohnya indikator tentang kemampuan siswa dalam mengidentifikasi sumber-sumber energi yang ada di sekitarnya. Kegiatan belajar mengajar yang menggunakan metode konvensional yaitu ceramah, diskusi dan tanya jawab tetap diberlakukan.

Oleh karena itu, dalam penelitian ini dirumuskan dua permasalahan, yaitu adakah pengaruh penerapan model inkuiri terbimbing terhadap kemandirian belajar siswa kelas 2 sekolah dasar homeschooling pada mata pelajaran IPA?, serta adakah pengaruh penerapan model inkuiri terbimbing terhadap kemampuan siswa dalam mengidentifikasi sumber-sumber energi yang ada di lingkungan sekitar?.

\section{METODE}

Penelitian ini termasuk ke dalam kategori penelitian kuantitatif dengan jenis metode penelitian experimental design dengan bentuk pretest dan posttest group design. Penelitian ini melibatkan dua kelompok yang masing-masing terdiri dari kelompok eksperimen dan kelompok 
kontrol. Kelas yang mendapat perlakuan tersebut (menggunakan model pembelajaran IPA pada umumnya atau konvensional) disebut dengan kelas kontrol. Pada penelitian ini kelas eksperimen dan kelas kontrol diberikan pretest dan posttest dengan alat tes yang sama, sedangkan alat uji statistik pada penelitian ini menggunakan $U$-test (Mann Whitney) karena penelitian dilakukan pada kelompok kecil $\mathrm{n} \leq 30$. Jenis rancangan kuasi eksperimental antara lain, rancangan pretest dan posttest yang tidak ekuivalen (The non ekuivalen pretest posttest design).

Cresswell (2014) mengatakan desain penelitian adalah rencana dan tahapan untuk penelitian yang mencakup keputusan mulai dari asumsi yang luas hingga metode pengumpulan dan analisis data yang terperinci. Menurut Sukardi (2003), terdapat tiga jenis rancangan penelitian eksperimen, penelitian kali ini menggunakan desain atau rancangan eksperimen semu (penelitian quasi eksperimental). Desain eksperiman semu pada penelitian kali ini bertujuan untuk mengungkapkan sebab dan akibat, dengan cara melibatkan kelompok kontrol yang ada dan kelompok eksperimen yang akan diberikan treatment atau perlakuan, namun pemilahan kedua kelompok tersebut tidak dengan teknik acak atau tidak dilakukan dengan random sampling. Desain penelitian pada penelitian ini hampir sama dengan dengan rancangan penelitian secara konvensional, yaitu untuk melihat hubungan kausal dari berbagai macam kondisi, namun tidak dengan cara acak atau random. Sementara itu menurut Best (dalam Prasetyo \& Jannah, 2005), penelitian dengan desain eksperimen semu memiliki kontrol yang lebih baik daripada praeksperimen. Namun pada penelitian desain eksperimen semu memiliki kelemahan yakni tak mencapai ekuivalensi antara eksperimen dan kelompok kontrol. Penelitian kuasi eksperimen ini menggunakan metode percobaan untuk mempelajari pengaruh dari variabel tertentu yang ingin diteliti terhadap variabel lain, melalui uji coba dalam kondisi khusus yang sengaja diciptakan oleh peneliti (treatment). Desain penelitian ini merupakan nonequivalen control group design dimana sampel tidak dipilih secara acak atau random.

\section{HASIL DAN PEMBAHASAN}

Untuk membuktikan keakuratan metode dari instrumen yang digunakan oleh peneliti pada pengambilan data, maka peneliti menyajikan penilaian hasil dari uji kevalidan, uji instrumen penelitian, uji prasyarat, dan uji hipotesis.

Hasil

Uji Validasi Perangkat Pembelajaran Ipa Dengan Model Inkuiri Terbimbing Untuk Materi Bayangan Dan Cahaya

\section{Validasi Perangkat Pembelajaran Rencana Pelaksanaan Pembelajaran (RPP)}

Untuk pengujian perangkat pembelajaran berupa Rencana Pelaksanaan Pembelajaran (RPP) diperlukan seorang ahli untuk menguji validasi tiap komponen yang dinilai di dalam sebuah RPP, seperti struktur dan kesesuaian identitas sekolah. Sistematika isi, kelengkapan Kompetensi Dasar (KD), dan indikator. Serta tahapan atau sintaks (fase-fase) didalam proses pembelajaran yang dijabarkan di dalam RPP tersebut. Hasil penilaian dari validator untuk instrumen penilaian kevalidan RPP dapat dilihat pada Tabel 1 dan Tabel 2.

Tabel 1. Hasil Penilaian Identitas RPP

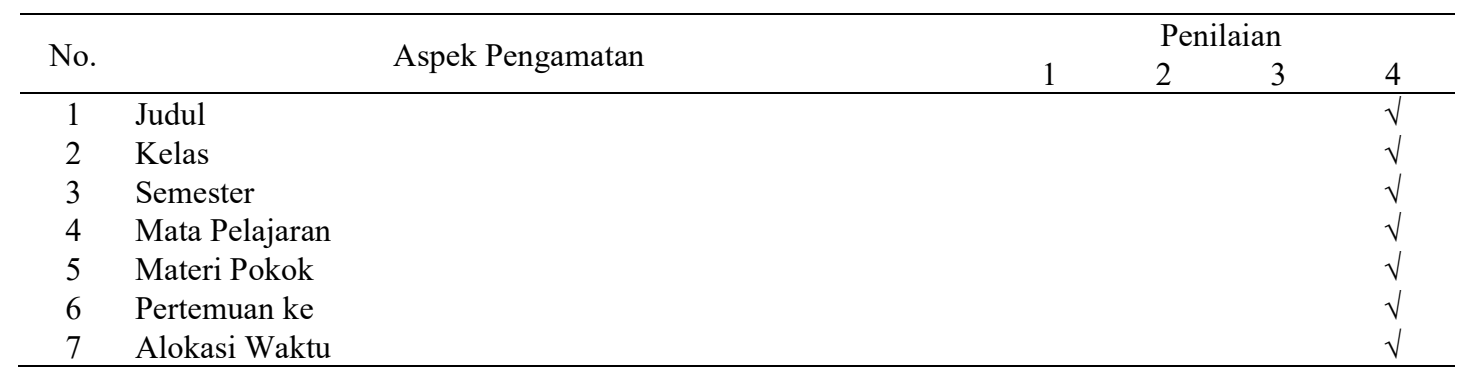


Tabel 2. Hasil Penilaian Sistematika RPP

\begin{tabular}{|c|c|c|c|c|c|}
\hline \multirow{2}{*}{ No. } & \multirow{2}{*}{ Aspek Pengamatan } & \multicolumn{4}{|c|}{ Penilaian } \\
\hline & & 1 & 2 & 3 & 4 \\
\hline \multirow[t]{6}{*}{1} & Kompetensi (Kode KI harus ditulis) & & & & $\sqrt{ }$ \\
\hline & Kompetensi Dasar dan Idikator & & & & \\
\hline & KD dan Indikator mewakili masing-masing KI dan sesuai & & $\sqrt{ }$ & & \\
\hline & Penomoran KI, KD, dan Indikator tersusun sesuai urutan & & & $\sqrt{ }$ & \\
\hline & KD dan Indikator ditulis secara jelas & & & $\sqrt{ }$ & \\
\hline & $\begin{array}{l}\text { Indikator di RPP sesuai dengan Indikator yang tertera di } \\
\text { silabus }\end{array}$ & & $\sqrt{ }$ & & \\
\hline \multirow[t]{6}{*}{2} & $\begin{array}{l}\text { Rumusan pada indikator cukup di tulis B-nya (behavior) } \\
\text { saja (kata kerja operasional dan substansinya) }\end{array}$ & & $\sqrt{ }$ & & \\
\hline & $\begin{array}{l}\text { Indikator diuraui dalam kemampuan pemecahan masalah } \\
\text { peserta didik }\end{array}$ & & & $\sqrt{ }$ & \\
\hline & $\begin{array}{l}\text { Penomoran indikator ada tiga aspek, yaitu aspek } 1 \\
\text { kompetensi inti, aspek } 2 \text { kompetensi dasar, aspek } 3 \text { nomor } \\
\text { urutan pembelajaran }\end{array}$ & & $\sqrt{ }$ & & \\
\hline & Tujuan Pembelajaran & & & & \\
\hline & Tujuan Pembelajaran di muat di dalam RPP & & & & $\sqrt{ }$ \\
\hline & $\begin{array}{l}\text { Tujuan Pembelajaran tersusun atas indikator (satu } \\
\text { indikator disusun untuk satu tujuan pembelajaran) }\end{array}$ & & & $\sqrt{ }$ & \\
\hline \multirow{2}{*}{3} & $\begin{array}{l}\text { Rumusan tujuan pembelajaran (menggunakan konsep } \\
\text { ABCD) }\end{array}$ & & $\sqrt{ }$ & & \\
\hline & $\begin{array}{l}\text { Penomoran tujuan pembelajaran sesuai dengan penomoran } \\
\text { pada indicator }\end{array}$ & & $\sqrt{ }$ & & \\
\hline 4 & $\begin{array}{l}\text { Materi pembelajaran cukup ditulis pokok-pokok/topik } \\
\text { materi }\end{array}$ & & & $\sqrt{ }$ & \\
\hline 5 & $\begin{array}{l}\text { Pendekatan (Model/Metode) sesuai dengan } \\
\text { indikator/tujuan pembelajaran. }\end{array}$ & & $\sqrt{ }$ & & \\
\hline \multirow[t]{4}{*}{6} & $\begin{array}{l}\text { Media, alat, dan bahan menunjang ketercapaian indikator } \\
\text { Langkah-langkah kegiatan pembelajaran }\end{array}$ & & & $\sqrt{ }$ & \\
\hline & Pendahuluan & & & & $\sqrt{ }$ \\
\hline & Kegiatan Inti & & & & \\
\hline & Identifikasi masalah & & & $\sqrt{ }$ & \\
\hline \multirow[t]{5}{*}{7} & Menentukan srategi & & $\sqrt{ }$ & & \\
\hline & Mengekplorasi ide/gagasan & & $\sqrt{ }$ & & \\
\hline & Melakukan tindakan dan mengkomunikasikan & & & $\sqrt{ }$ & \\
\hline & Melakukan refleksi dan berbagi & & & $\sqrt{ }$ & \\
\hline & Penutup & & & $\sqrt{ }$ & \\
\hline 8 & $\begin{array}{l}\text { Sumber pembelajaran melampirkan seluruh sumber } \\
\text { pembelajaran yang digunakan dalam RPP }\end{array}$ & & $\sqrt{ }$ & & \\
\hline 9 & Mencantumkan daftar pustaka dengan jelas & & $\sqrt{ }$ & & \\
\hline
\end{tabular}




\section{Validitas Perangkat Pembelajaran Silabus}

Perangkat pembelajaran kedua yang diuji kevalidannya dalam penelitian ini adalah silabus. Hasil validasi silabus yang digunakan peneliti pada saat pembelajaran di kelas yang telah dinyatakan valid oleh validator dapat dilihat pada Tabel 3 .

Tabel 3. Hasil Uji Validitas Silabus

\begin{tabular}{|c|c|c|c|c|c|}
\hline \multirow{2}{*}{ No. } & \multirow{2}{*}{ Aspek Penilaian } & \multicolumn{4}{|c|}{ Penilaian } \\
\hline & & 1 & 2 & 3 & 4 \\
\hline 1 & Dibuat untuk setiap pertemuan & & $\sqrt{ }$ & & \\
\hline \multirow[t]{6}{*}{2} & Identitas silabus & & & & \\
\hline & Judul & & $\sqrt{ }$ & & \\
\hline & Kelas & & & & $\sqrt{ }$ \\
\hline & Semester & & & & $\sqrt{ }$ \\
\hline & Mata pelajaran & & & & $\sqrt{ }$ \\
\hline & Materi pokok & & & $\sqrt{ }$ & \\
\hline \multirow[t]{9}{*}{3} & Format tabel silabus & & & & \\
\hline & Kompetensi inti & & & $\sqrt{ }$ & \\
\hline & Kompetensi dasar & & & $\sqrt{ }$ & \\
\hline & Indikator & & $\sqrt{ }$ & & \\
\hline & Kegiatan Pembelajaran & & $\sqrt{ }$ & & \\
\hline & Penilaian (teknik, bentuk instrumen) & & $\sqrt{ }$ & & \\
\hline & Alokasi waktu & & & & $\sqrt{ }$ \\
\hline & Sumber belajar & & & $\sqrt{ }$ & \\
\hline & Tata tulis & & $\sqrt{ }$ & & \\
\hline
\end{tabular}

\section{Validitas Perangkat Pembelajaran Latihan Soal (Worksheet)}

Perangkat pembelajaran ketiga yang diuji kevalidannya dalam penelitian ini adalah perangkat pembelajaran latihan soal (worksheet). Hasil validasi perangkat pembelajaran latihan soal yang digunakan peneliti pada saat pembelajaran di kelas yang telah dinyatakan valid oleh validator dapat dilihat pada Tabel 4.

Tabel 4. Hasil Validitas Perangkat Pembelajaran Latihan Soal (Worksheet)

\begin{tabular}{|c|c|c|c|c|}
\hline No. & Kompetensi Dasar & Soal & $\begin{array}{l}\text { Tipe } \\
\text { Soal }\end{array}$ & $\begin{array}{c}\text { Kunci } \\
\text { Jawaban }\end{array}$ \\
\hline 1. & $\begin{array}{l}\text { Mengenali enam macam sumber energi } \\
\text { yang ada di sekitar manusia beserta } \\
\text { kegunaannya }\end{array}$ & $\begin{array}{l}\text { Televisi dapat mengeluarkan energi } \\
\text { bunyi dan ....(a) Suara; (b) Panas: (c) } \\
\text { Listrik }\end{array}$ & $\mathrm{C} 1$ & $\mathrm{C}$ \\
\hline 2. & $\begin{array}{l}\text { Mengenali enam macam sumber energi } \\
\text { yang ada di sekitar manusia beserta } \\
\text { kegunaannya }\end{array}$ & $\begin{array}{l}\text { Menggunakan energi listrik harus } \\
\text { dengan ... (a) Ceroboh; (b) Boros; } \\
\text { (c) Hemat }\end{array}$ & $\mathrm{C} 2$ & $\mathrm{C}$ \\
\hline 3. & $\begin{array}{l}\text { Mengenali enam macam sumber energi } \\
\text { yang ada di sekitar manusia beserta } \\
\text { kegunaannya }\end{array}$ & $\begin{array}{l}\text { Senter adalah benda yang dapat } \\
\text { memancarkan energi ... (a) Suara; (b) } \\
\text { Listrik; (c) Cahaya }\end{array}$ & $\mathrm{C} 1$ & $\mathrm{C}$ \\
\hline 4. & $\begin{array}{l}\text { Mengenali enam macam sumber energi } \\
\text { yang ada di kehidupan sehari-hari } \\
\text { beserta kegunaannya }\end{array}$ & $\begin{array}{l}\text { Lampu adalah benda yang } \\
\text { dimanfaatkan untuk ... (a) } \\
\text { Penerangan; (b) Pendingin; (c) } \\
\text { Pemanas }\end{array}$ & $\mathrm{C} 1$ & A \\
\hline 5. & $\begin{array}{l}\text { Mengenali enam macam sumber energi } \\
\text { yang ada di sekitar manusia beserta } \\
\text { kegunaannya }\end{array}$ & $\begin{array}{l}\text { Perabot sehari-hari yang } \\
\text { menggunakan energi gerak adalah ... } \\
\text { (a) Lampu; (b) Kompor; (c) Kipas }\end{array}$ & $\mathrm{C} 1$ & $\mathrm{C}$ \\
\hline
\end{tabular}




\begin{tabular}{|c|c|c|c|c|}
\hline 6. & $\begin{array}{l}\text { Mengenali enam macam sumber energi } \\
\text { yang ada di kehidupan sehari-hari } \\
\text { beserta kegunaannya }\end{array}$ & $\begin{array}{l}\text { Kompor mengeluarkan energi panas } \\
\text { yang digunakan untuk keperluan ... } \\
\text { (a) Memasak; (b) Mencuci; (c) } \\
\text { Menyetrika }\end{array}$ & $\mathrm{C} 1$ & A \\
\hline 7. & $\begin{array}{l}\text { Mengenali enam macam sumber energi } \\
\text { yang ada di kehidupan sehari-hari } \\
\text { beserta kegunaannya }\end{array}$ & $\begin{array}{l}\text { Setrika digunakan manusia untuk ... } \\
\text { (a) Merapikan tanaman; (b) } \\
\text { Merapikan baju; (c) Merapikan } \\
\text { tulisan }\end{array}$ & $\mathrm{C} 1$ & B \\
\hline 8. & $\begin{array}{l}\text { Mengenali enam macam sumber energi } \\
\text { yang ada di kehidupan sehari-hari } \\
\text { beserta kegunaannya }\end{array}$ & $\begin{array}{l}\text { Lampu dapat menyala karena } \\
\text { memiliki energi ... (a) Panas; (b) } \\
\text { Bunyi; (c) Listrik }\end{array}$ & $\mathrm{C} 1$ & $\mathrm{C}$ \\
\hline 9. & $\begin{array}{l}\text { Mengenali enam macam sumber energi } \\
\text { yang ada di kehidupan sehari-hari } \\
\text { beserta kegunaannya }\end{array}$ & $\begin{array}{l}\text { Apabila rumahmu terlihat gelap, } \\
\text { maka kamu membutuhkan energi ... } \\
\text { (a) Cahaya; (b) Bunyi; (c) Panas }\end{array}$ & $\mathrm{C} 1$ & A \\
\hline 10. & $\begin{array}{l}\text { Mengenali enam macam sumber energi } \\
\text { yang ada di kehidupan sehari-hari } \\
\text { beserta kegunaannya }\end{array}$ & $\begin{array}{l}\text { Radio digunakan manusia untuk ... } \\
\begin{array}{ll}\text { (a) Melihat sinetron; (b) Menonton } \\
\text { pertandingan bulu tangkis; (c) } \\
\text { Mendengarkan berita }\end{array}\end{array}$ & $\mathrm{C} 1$ & $\mathrm{C}$ \\
\hline 11. & $\begin{array}{l}\text { Mendeskripsikan konsep terbentuknya } \\
\text { bayangan di kehidupan sehari-hari. }\end{array}$ & $\begin{array}{l}\text { Matahari dapat kita lihat jelas pada } \\
\text {... (a) Malam hari; (b) Siang hari; (c) } \\
\text { Fajar }\end{array}$ & $\mathrm{C} 1$ & B \\
\hline 12. & $\begin{array}{l}\text { Mendeskripsikan konsep terbentuknya } \\
\text { bayangan di kehidupan sehari-hari. }\end{array}$ & $\begin{array}{l}\text { Matahari mengeluarkan energi ... } \\
\text { untuk menyinari bumi. (a) Panas; (b) } \\
\text { Bunyi; (c) Cahaya }\end{array}$ & $\mathrm{C} 1$ & $\mathrm{C}$ \\
\hline 13. & $\begin{array}{l}\text { Mendeskripsikan konsep terbentuknya } \\
\text { bayangan di kehidupan sehari-hari. }\end{array}$ & $\begin{array}{l}\text { Sinar matahari tidak akan terlihat } \\
\text { jelas pada saat ada ... (a) Panas; (b) } \\
\text { Mendung; (c) Gerimis }\end{array}$ & $\mathrm{C} 2$ & B \\
\hline 14. & $\begin{array}{l}\text { Mendeskripsikan konsep terbentuknya } \\
\text { bayangan di kehidupan sehari-hari. }\end{array}$ & $\begin{array}{l}\text { Di sore hari matahari akan terlihat } \\
\text { warna ... (a) Kekuning-kuningan; (b) } \\
\text { Kemerah-merahan; (c) Kehitam- } \\
\text { hitaman }\end{array}$ & C3 & B \\
\hline 15. & $\begin{array}{l}\text { Mendeskripsikan konsep terbentuknya } \\
\text { bayangan di kehidupan sehari-hari. }\end{array}$ & $\begin{array}{l}\text { Di siang hari matahari akan tepat } \\
\text { berada di ... (a) Atas kepala; (b) } \\
\text { Sebelah tenggara; (c) Sebelah timur }\end{array}$ & $\mathrm{C} 1$ & A \\
\hline
\end{tabular}

\section{Deskripsi Jawaban Responden}

Berdasarkan hasil penyebaran kuisioner kepada responden penelitian yang dilakukan, distribusi sebaran jawaban responden terhadap tiap-tiap pernyataan yang tercantum dalam kuisioner untuk mengukur kemandirian belajar siswa kelas 2 SD Homeschooling Sinergia International Surabaya pada mata pelajaran IPA materi Cahaya dan Bayangan dapat dilihat pada Tabel 5 dan Tabel 6. Adapun jumlah angket yang disebar adalah sebanyak 20 eksemplar sesuai dengan jumlah populasi dengan siswa yang mengisi kuisioner sebanyak 18 karena pada saat penyebaran kuisioner terdapat 2 siswa yang sedang sakit, sehingga tidak dapat mengisi kuisioner. Dalam proses pengisian kuisioner, siswa didampingi oleh guru, beberapa diantaranya juga tidak hanya didamping oleh guru saja, tetapi juga didampingi oleh orang tua siswa, untuk menuntun mereka dalam memahami isi kuisioner.

Berdasarkan Tabel 5 dan Tabel 6 diketahui bahwa rata-rata siswa kelompok kontrol jarang melakukan hal-hal yang menunjukkan kemandirian dalam proses belajar, sementara rata-rata siswa kelompok eksperimen sering melakukan aktivitas yang menunjukkan kemandirian dalam proses belajar. Jadi, secara umum, rata-rata siswa dalam kelompok eksperimen lebih mandiri dalam proses belajar dibandingkan dengan kelompok kontrol. 
Tabel 5. Distribusi Frekuensi Jawaban Responden Terhadap Pernyataan dalam Kuisioner yang Mengukur Keberhasilan Kemandirian Siswa Kelompok Kontrol

\begin{tabular}{|c|c|c|c|c|c|c|c|c|c|c|c|c|}
\hline \multirow{3}{*}{ Item } & \multicolumn{10}{|c|}{ Jawaban Responden } & \multirow{3}{*}{ Mean } & \multirow{3}{*}{ Keterangan } \\
\hline & \multicolumn{2}{|c|}{1 (TP) } & \multicolumn{2}{|c|}{$2(\mathrm{KD})$} & \multicolumn{2}{|c|}{$3(\mathrm{~J})$} & \multicolumn{2}{|c|}{$4(\mathrm{~S})$} & \multicolumn{2}{|c|}{$5(\mathrm{SL})$} & & \\
\hline & $\mathrm{F}$ & $\%$ & $\mathrm{f}$ & $\%$ & $\mathrm{f}$ & $\%$ & $\mathrm{f}$ & $\%$ & $\mathrm{f}$ & $\%$ & & \\
\hline 1 & 0 & 0,0 & 0 & 0,0 & 6 & 66,7 & 2 & 22,2 & 1 & 11,1 & 3,44 & Jarang \\
\hline 2 & 0 & 0,0 & 0 & 0,0 & 7 & 77,8 & 2 & 22,2 & 0 & 0,00 & 3,22 & Jarang \\
\hline 3 & 0 & 0,0 & 0 & 0,0 & 5 & 55,6 & 4 & 44,4 & 0 & 0,0 & 3,44 & Jarang \\
\hline 4 & 0 & 0,0 & 2 & 22,2 & 5 & 55,6 & 2 & 22,2 & 0 & 0,0 & 3,00 & Jarang \\
\hline 5 & 1 & 11,1 & 2 & 22,2 & 5 & 55,6 & 0 & 0,0 & 1 & 11,1 & 2,78 & Jarang \\
\hline 6 & 0 & 0,0 & 0 & 0,0 & 3 & 33,3 & 4 & 44,4 & 2 & 22,2 & 3,89 & Sering \\
\hline 7 & 0 & 0,0 & 2 & 22,2 & 2 & 22,2 & 5 & 55,6 & 0 & 0,0 & 3,33 & Jarang \\
\hline 8 & 0 & 0,0 & 0 & 0,0 & 2 & 22,2 & 6 & 66,7 & 1 & 11,1 & 3,89 & Sering \\
\hline 9 & 0 & 0,0 & 0 & 0,0 & 3 & 33,3 & 6 & 66,7 & 0 & 0,0 & 3,67 & Sering \\
\hline 10 & 0 & 0,0 & 0 & 0,0 & 1 & 11,1 & 7 & 77,8 & 1 & 11,1 & 4,00 & Sering \\
\hline & & & & Rata-1 & & & & & & & 3,47 & Jarang \\
\hline
\end{tabular}

Tabel 6. Distribusi Frekuensi Jawaban Responden Terhadap Pernyataan dalam Kuisioner yang Mengukur Keberhasilan Kemandirian Siswa Kelompok Eksperimen

\begin{tabular}{|c|c|c|c|c|c|c|c|c|c|c|c|c|}
\hline \multirow{3}{*}{ Item } & \multicolumn{10}{|c|}{ Jawaban Responden } & \multirow{3}{*}{ Mean } & \multirow{3}{*}{ Keterangar } \\
\hline & \multicolumn{2}{|c|}{$1(\mathrm{TP})$} & \multicolumn{2}{|c|}{$2(\mathrm{KD})$} & \multicolumn{2}{|c|}{$3(\mathrm{~J})$} & \multicolumn{2}{|c|}{$4(\mathrm{~S})$} & \multicolumn{2}{|c|}{$5(\mathrm{SL})$} & & \\
\hline & $\mathrm{f}$ & $\%$ & $\mathrm{f}$ & $\%$ & $\mathrm{f}$ & $\%$ & $\mathrm{f}$ & $\%$ & $\mathrm{f}$ & $\%$ & & \\
\hline 1 & 0 & 0,0 & 0 & 0,0 & 2 & 22,2 & 5 & $\overline{55,6}$ & 2 & 22,2 & 4,00 & Sering \\
\hline 2 & 0 & 0,0 & 1 & 11,1 & 2 & 22,2 & 4 & 44,4 & 2 & 22,2 & 3,78 & Sering \\
\hline 3 & 0 & 0,0 & 0 & 0,0 & 2 & 22,2 & 2 & 22,2 & 5 & 55,6 & 4,33 & Sering \\
\hline 4 & 0 & 0,0 & 1 & 11,1 & 2 & 22,2 & 3 & 33,3 & 3 & 33,3 & 3,89 & Sering \\
\hline 5 & 1 & 5,6 & 2 & 22,2 & 4 & 44,4 & 1 & 11,1 & 2 & 22,2 & 3,33 & Jarang \\
\hline 6 & 0 & 0,0 & 0 & 0,0 & 0 & 0,0 & 5 & 55,4 & 4 & 44,4 & 4,44 & Sering \\
\hline 7 & 0 & 0,0 & 0 & 0,0 & 3 & 33,3 & 4 & 44,4 & 2 & 22,2 & 3,89 & Sering \\
\hline 8 & 0 & 0,0 & 0 & 0,0 & 1 & 11,1 & 4 & 44,4 & 4 & 44,4 & 4,33 & Sering \\
\hline 9 & 0 & 0,0 & 0 & 0,0 & 1 & 11,1 & 3 & 33,3 & 5 & 55,6 & 4,44 & Sering \\
\hline 10 & 0 & 0,0 & 0 & 0,0 & 0 & 0,0 & 3 & 33,3 & 6 & 66,7 & 4,67 & Selalu \\
\hline & & & & Rata & lata & & & & & & 4,11 & Sering \\
\hline
\end{tabular}

Uji Instrumen Penelitian

Dalam penelitian ini menggunakan instrumen penelitian berupa kuisioner berskala likert 5 point yang terdiri dari 10 item pernyataan yang diberikan kepada responden penelitian, yaitu para siswa, baik dari kelompok kontrol maupun eksperimen. Sebelum hasil kuisioner (data jawaban responden) dianalisis secara inferensial, maka kuisioner harus memenuhi uji validitas dan reliabilitas terlebih dahulu. Validitas adalah suatu ukuran yang dapat menunjukkan tingkat keabsahan suatu perangkat tes, serta untuk mengukur sejauh mana ketepatan dan kecermatan suatu alat ukur tersebut dalam melakukan fungsi ukurnya, atau dengan kata lain dapat dikatakan sebagai suatu derajat ketepatan atau kelayakan instrumen yang akan digunakan untuk mengukur variabel yang akan diukur (Arikunto, 2013).

Sedangkan Reliabilitas menurut Sugiyono (2015) adalah serangkaian pengukuran atau serangkaian alat ukur yang memiliki konsistensi apabila pengukuran tersebut dilakukan dengan alat 
ukur tersebut, dan dilakukan secara berulang. Jadi, reabilitas merupakan suatu tingkatan yang mengukur konsistensi hasil penelitian khususnya data kuantitatif dari suatu kuisioner.

Uji Validitas

Suatu instrumen penelitian dikatakan valid jika nilai Sig (2-tailed) di setiap variabel penelitian terhadap variabel total kurang dari taraf signifikansi yang diambil (Sig. (2-tailed) $<\alpha=0,05$ ). Berdasarkan Tabel 7, diketahui bahwa semua nilai R-hitung setiap item penelitian lebih besar dari R-tabel, demikian juga nilai Sig. (2-tailed) Pearson Correlation terhadap variabel total setiap item < 0,05 (taraf signifikansi atau $\alpha$ ). Hal ini menunjukkan bahwa instrumen penelitian, dalam hal ini kuesioner yang digunakan untuk mengukur kemandirian belajar siswa kelas 2 SD homeschooling Sinergia International Surabaya pada mata pelajaran IPA materi Cahaya dan Bayangan valid atau sah.

Tabel 7. Hasil Uji Validitas

\begin{tabular}{cccccc}
\hline Item & R-hitung & R-tabel & Sig. (2-tailed) & $\alpha$ & Kesimpulan \\
\hline 1 & 0,545 & 0,4683 & 0,019 & 0,05 & Valid \\
2 & 0,577 & 0,4683 & 0,012 & 0,05 & Valid \\
3 & 0,600 & 0,4683 & 0,008 & 0,05 & Valid \\
4 & 0,572 & 0,4683 & 0,013 & 0,05 & Valid \\
5 & 0,774 & 0,4683 & 0,000 & 0,05 & Valid \\
6 & 0,647 & 0,4683 & 0,004 & 0,05 & Valid \\
7 & 0,522 & 0,4683 & 0,026 & 0,05 & Valid \\
8 & 0,493 & 0,4683 & 0,038 & 0,05 & Valid \\
9 & 0,610 & 0,4683 & 0,007 & 0,05 & Valid \\
10 & 0,571 & 0,4683 & 0,013 & 0,05 & Valid \\
\hline
\end{tabular}

\section{Uji Reliabilitas}

Hair Jr, Matthews, Matthews, dan Sarstedt (2010) mengatakan bahwa suatu kondisi dinyatakan reliabel jika nilai Cronbach's Alpha lebih dari 0,70, sedangkan menurut Ghozali (2011) suatu variabel dapat dikatakan reliabel jika memberikan nilai Cronbach's Alpha $(\alpha)>0,6$. Sebagaimana uji validitas, karena ada 10 item pernyataan dalam kuisioner, maka kesepuluh item tersebut juga perlu diuji reliabilitasnya, karena instrumen harus valid dan reliabel.

Tabel 8. Hasil Uji Reliabilitas

\begin{tabular}{cccc}
\hline Item & Cronbach's Alpha if Item Deleted & Ketentuan & Kesimpulan \\
\hline 1 &, 778 & $>0,6$ & Reliabel \\
2 &, 774 & $>0,6$ & Reliabel \\
3 &, 772 & $>0,6$ & Reliabel \\
4 &, 783 & $>0,6$ & Reliabel \\
5 &, 746 & $>0,6$ & Reliabel \\
6 &, 765 & $>0,6$ & Reliabel \\
7 &, 784 & $>0,6$ & Reliabel \\
8 &, 783 & $>0,6$ & Reliabel \\
9 &, 769 & $>0,6$ & Reliabel \\
10 &, 774 & $>0,6$ & Reliabel \\
\hline
\end{tabular}


Berdasarkan pada Tabel 8 hasil uji reliabilitas diketahui bahwa nilai Cronbach's Alpha setiap item yang penelitian lebih besar dari 0,6 . Hal tersebut yang berarti bahwa instrumen penelitian, dalam hal ini kuesioner yang digunakan untuk mengukur mengukur kemandirian belajar siswa kelas 2 SD homeschooling Sinergia International Surabaya pada mata pelajaran IPA materi cahaya dan bayangan reliabel atau handal atau konsisten.

\section{Uji Prasyarat}

Data primer hasil kuisioner yang telah valid dan reliabel maupun data sekunder hasil pretest dan postest selanjutnya akan diuji distribusi datanya. Jika data berdistribusi secara normal maka uji hipotesis dapat dilakukan melalui compare means $t$-test, sedangkan jika tidak normal maka dapat menggunakan non parametric test seperti Mann Whitney U test. Uji Mann Whitney U test digunakan untuk mengetahui perbedaan rerata dua sampel yang tidak berpasangan dan uji Wilcoxon untuk mengetahui perbedaan rerata dua sampel yang berpasangan, yaitu sampel yang sama namun sampel yang memiliki data ganda.

\section{Uji Normalitas}

Uji normalitas digunakan untuk mengetahui apakah data pada penelitian terdistribusi normal atau tidak, karena hal ini berkaitan dengan uji hipotesis yang akan dilakukan. Normalitas data dapat diuji menggunakan uji Kolmogorov-Smirnov. Suatu data dikatakan terdistribusi secara normal jika nilai Sig. kolmogorov-Smirnov lebih besar dari taraf signifikansi yang diambil (Sig. Kolmogorov Smirnov $>\alpha=0,05$ ) jika jumlah sampel lebih dari 30, namun jika kurang dari 30 digunakan nilai Sig. Shapiro-Wilk (Sig. Shapiro Wilk $>\alpha=0,05$ ).

Tabel 9. Hasil Uji Normalitas

\begin{tabular}{lrrrrrr}
\hline & \multicolumn{3}{c}{ Kolmogorov-Smirnov $^{\text {a }}$} & \multicolumn{3}{c}{ Shapiro-Wilk } \\
& Statistic & df & \multicolumn{1}{c}{ Sig. } & Statistic & df & \multicolumn{1}{l}{ Sig. } \\
\hline Kuisioner kelas kontrol & .338 & 9 & .004 & .768 & 9 & .009 \\
Kuisioner kelas eksperimen & .208 & 9 & $.200^{*}$ & .850 & 9 & .074 \\
Kontrol pretest & .205 & 9 & $.200^{*}$ & .912 & 9 & .327 \\
Ekperimen pretest & .247 & 9 & .119 & .915 & 9 & .351 \\
Kontrol postest & .156 & 9 & $.200^{*}$ & .938 & 9 & .557 \\
Ekperimen postest & .167 & 9 & $.200^{*}$ & .963 & 9 & .830 \\
\hline
\end{tabular}

*. This is a lower bound of the true significance

a. Lilliefors Significance Correction

Berdasarkan Tabel 9, diketahui bahwa nilai Sig. Shapiro Wilk pada data hasil kuisioner kelompok kontrol sebesar 0,009<0,05; sedangkan Sig. Shapiro Wilk data hasil kuisioner kelompok eksperimen sebesar $0,074>0,05$. Hal tersebut menunjukkan bahwa dari data hasil kuisioner kelompok kontrol tidak terdistribusi secara normal, sedangkan data hasil kuisioner kelompok eksperimen terdistribusi secara normal. Adapun nilai Sig. Shapiro Wilk data nilai pretest kelompok kontrol sebesar 0,327>0,05; nilai Sig. Shapiro Wilk data nilai pretest kelompok eksperimen sebesar $0,351>0,05$; nilai Sig. Shapiro Wilk data nilai postest kelompok kontrol sebesar 0,557>0,05 dan nilai Sig. Shapiro Wilk data nilai postest kelompok eksperimen sebesar $0,830>0,05$. Hal Ini menunjukkan bahwa semua nilai pretest maupun postest baik siswa dari kelompok kontrol maupun eksperimen terdistribusi secara normal.

\section{Uji Homogenitas}

Uji homogenitas pada penelitian ini menggunakan uji test of homogenity, yang memiliki tujuan untuk mengetahui apakah sampel yang digunakan pada penelitian ini memiliki varian yang sama atau tidak. Data dapat dikatakan memiliki varian yang sama apabila Sig. $>\alpha=0,05$, dan sebaliknya, data memiliki varian yang tidak sama jika Sig. $<\alpha=0,05$. Data hasil uji homogenitas dapat dilihat pada Tabel 10. Berdasarkan data pada Tabel 10, diketahui bahwa Sig. Lavene hasil kuisioner sebesar 0,154>0,05, kemudian nilai Sig. Lavene pretest siswa sebesar 0,717 >0,05, 
demikian juga dengan Sig. Lavene postest siswa sebesar 0,433 >0,05, maka data hasil kuisioner baik data nilai pretest maupun postest siswa memiliki varian yang sama atau homogen. Oleh karena terdapat 1 data yang tidak berdistribusi secara normal, yaitu data hasil kuisioner dari kelompok kontrol, maka dilakukan uji hipotesis menggunakan analisis non-parametrik, yaitu Mann Whitney utest dan Wilcoxon.

Tabel 10. Hasil Uji Homogenitas Varians

\begin{tabular}{lcccc}
\hline & Levene Statistic & df1 & df2 & Sig. \\
\hline Hasil kuisioner & 2.239 & 1 & 16 & .154 \\
Pretest & .136 & 1 & 16 & .717 \\
Postest & .647 & 1 & 16 & .433 \\
\hline
\end{tabular}

\section{Uji Hipotesis}

\section{Mann Whitney U-test}

Uji Mann Whitney U-test digunakan untuk mengetahui apakah terdapat perbedaan rata-rata pada dua sampel yang tidak berpasangan, dengan syarat uji statistik parametrik berupa data tidak berdistribusi secara normal. Dalam penelitian ini, uji Mann Whitney U-test dihunakan untuk membuktikan hipotesis penelitian yang pertama, karena data yang digunakan adalah data jawaban responden terhadap setiap item pernyataan yang disajikan dalam kuisioner. Sementara sampel dalam penelitian ini terdapat 2 macam, yaitu kelompok kontrol dan kelompok eksperimen (dua sampel yang tidak berpasangan).

Adapun dasar pengambilan keputuasan adalah jika nilai Sig.(2-tailed) $<0,05$, maka terdapat perbedaan yang signifikan antara hasil belajar pada kelompok kontrol dan kelompok eksperimen. Sebaliknya, jika nilai Sig. (2-tailed) >0,05, maka tidak terdapat perbedaan yang signifikan antara hasil belajar pada kelompok kontrol dan kelompok eksperimen.

Tabel 11. Mean Ranks

\begin{tabular}{llccc}
\hline & Kelas & N & Mean Rank & Sum of Ranks \\
\hline \multirow{3}{*}{ Hasil } & Kelompok kontrol & 9 & 5.61 & 50.50 \\
& Kelompok eksperimen & 9 & 13.39 & 120.50 \\
& Total & 18 & & \\
\hline
\end{tabular}

Tabel 11 merupakan deskriptif data yang telah melalui Mann Whitney U-test, yaitu data yang berasal dari penyebaran kuisioner. Berdasarkan data dalam Tabel 11 diketahui bahwa jumlah siswa pada kelompok kontrol dan kelompok eksperimen sama, yaitu masing-masing sebanyak 9 siswa. Adapun nilai mean rank kelompok kontrol lebih kecil dari pada kelompok eksperimen $(5,61$ $<13,39$ ). Demikian juga dengan nilai sum of rank kelompok kontrol juga lebih kecil dari kelompok eksperimen $(50,50<120,50)$. Nilai tersebut menunjukkan bahwa kemandirian siswa yang mendapat pembelajaran dengan model inkuiri terbimbing lebih tinggi dibandingkan dengan siswa dari kelompok kontrol yang tidak mendapatkan pembelajaran melalui model inkuiri terbimbing. Untuk menguatkan keberhasilan pembelajaran dengan model inkuiri terbimbing tersebut terhadap kemandirian siswa dapat dilihat pada Tabel 12 hasil independent samples test.

Berdasarkan data dalam pada Tabel 12, diketahui bahwa nilai Asymp. Sig. (2-tailed) sebesar $0,002<0,05$ yang artinya terdapat perbedaan yang signifikan antara hasil belajar pada kelompok kontrol dan kelompok eksperimen. Hal ini menunjukkan bahwa hipotesis penelitian pertama (H1) yang menyatakan bahwa: Ada pengaruh model inkuiri terbimbing terhadap kemandirian belajar siswa kelas 2 SD homeschooling, diterima. Terbukti bahwa model inkuiri terbimbing dapat menjadikan siswa lebih mandiri dalam belajar. 
Tabel 12. Hasil Independent Samples Test

\begin{tabular}{lr}
\hline & Hasil \\
\hline Mann-Whitney U & 5.500 \\
Wilcoxon W & 50.500 \\
Z & -3.108 \\
Asymp. Sig. (2-tailed) & .002 \\
Exact Sig. [2*(1-tailed Sig.)] & $.001^{\mathrm{b}}$ \\
\hline
\end{tabular}

a. Grouping Variable: Kelas

b. Not corrected for ties.

\section{Wilcoxon Signed Test}

Uji Wilcoxon digunakan untuk mengetahui apakah terdapat perbedaan rata-rata dua sampel yang berpasangan yaitu sampel yang sama namun mempunyai dua data. Dalam penelitian ini, uji Wilcoxon dibutuhkan guna membuktikan hipotesis penelitian yang kedua, karena data yang digunakan adalah data pretest dan postest siswa. Data hasil pretest dan postest berasal dari sampel yang sama, artinya, dua sampel yang diambil dalam pretest dan postest tersebut berpasangan. Sementara jika uji Mann-Whitney U-test adalah uji yang digunakan untuk mengetahui perbedaan rata-rata dari dua sampel yang tidak berpasangan. Jadi, untuk menguji hipotesis yang kedua, sesuai dengan jenis sampel yang berpasangan, maka lebih tepat menggunakan Wilcoxon Signed Test. Uji Wilcoxon merupakan bagian dari statistik non-parametrik, sehingga memiliki prasyarat bahwa data tidak berdistribusi secara normal.

Tabel 13. Ranks Uji Wilcoxon untuk Membandingkan antara Nilai Pretest dan Posttest

\begin{tabular}{llccc}
\hline & & $\mathrm{N}$ & Mean Rank & Sum of Ranks \\
\hline Kontrol postest - kontrol pretest & Negative ranks & $0^{\mathrm{a}}$ & .00 & .00 \\
& Positive ranks & $8^{\mathrm{b}}$ & 4.50 & 36.00 \\
& Ties & $1^{\mathrm{c}}$ & & \\
& Total & 9 & & \\
\multirow{5}{*}{$\begin{array}{l}\text { Ekperimen postest - ekperimen } \\
\text { pretest }\end{array}$} & Negative ranks & $0^{\mathrm{d}}$ & .00 & .00 \\
& Positive ranks & $9^{\mathrm{e}}$ & 5.00 & 45.00 \\
& Ties & $0^{\mathrm{f}}$ & & \\
& Total & 9 & & \\
\hline
\end{tabular}

Data dalam Tabel 13 merupakan deskriptif dari data yang diuji melalui Wilcoxon Signed test, yaitu data nilai pretest dan postest siswa dari kelompok kontrol dan juga kelompok eksperimen. Dari data dalam Tabel 13 diketahui bahwa terdapat 8 siswa pada kelompok kontrol yang mendapatkan nilai postest lebih tinggi daripada saat pretest. Namun, ada seorang siswa dari kelompok kontrol ini yang nilai postest sama dengan nilai pretest, sedangkan pada kelompok eksperimen, seluruh siswa mendapatkan nilai postest yang lebih tinggi daripada saat pretest. Adapun nilai mean range maupun sum of range dari kelompok kontrol lebih rendah dibandingkan dengan kelompok eksperimen. Ini menunjukkan bahwa perlakuan yang diberikan yang di kelompok eksperimen yang dalam hal ini adalah model inkuiri terbimbing, cukup memberikan hasil positif bagi siswa dalam mengidentifikasi sumber-sumber energi yang ada di sekitar manusia.

Pada Tabel 14 disajikan output hasil uji Wilcoxon yang menunjukkan signifikan tidaknya perbedaan antara 2 sampel, yaitu data pretest dan postest kelompok kontrol dan kelompok eksperimen. Jika nilai Sig. $<0,05$ maka perbedaannya sangat signifikan di antara kedua data. Berdasarkan data dalam Tabel 14 dapat dilihat bahwa nilai Asymp. Sig. (2-tailed) kelompok kontrol sebesar $0,011<0,05$, artinya terdapat perbedaan nilai pretest dengan nilai postest yang signifikan di kelompok kontrol. Demikian juga dengan nilai Asymp. Sig. (2-tailed) kelompok eksperimen sebesar 
$0,007<0,05$ yang berarti bahwa terdapat perbedaan nilai postest dengan nilai pretest yang signifikan. Walau sama-sama menunjukkan hasil, namun nilai $Z$ di kelompok kontrol $<$ dari nilai $Z$ di kelompok eksperimen (-2,555 > -2,677), serta nilai Asymp. Sig. (2-tailed) di kelompok kontrol > nilai Asymp. Sig. (2-tailed) di kelompok eksperimen $(0,011>0,007)$ yang menunjukkan bahwa perbedaan nilai postest dengan pretest di kelompok eksperimen lebih signifikan dibandingkan di kelompok kontrol.

Tabel 14. Hasl Output Uji Wilcoxon

\begin{tabular}{lcc}
\hline & Kontrol Postest - Kontrol Pretest & Ekperimen Postest - Ekperimen Pretest \\
\hline$Z$ & $-2.555^{\mathrm{b}}$ & $-2.677^{\mathrm{b}}$ \\
Asymp. Sig. (2-tailed) & .011 & .007 \\
\hline a. Wilcoxon Signed Ranks Test & & \\
b. Based on negative ranks. & &
\end{tabular}

Tabel 15. Ranks Uji Wilcoxon untuk Membandingkan antara Nilai Pretest Kelompok Kontrol Dan Eksperimen serta Nilai Postest Kelompok Kontrol dan Eksperimen

\begin{tabular}{lllcc}
\hline & & $\mathrm{N}$ & Mean Rank & Sum of Ranks \\
\hline Ekperimen pretest - & Negative ranks & $4^{\mathrm{a}}$ & 3.75 & 15.00 \\
kontrol pretest & Positive ranks & $3^{\mathrm{b}}$ & 4.33 & 13.00 \\
& Ties & $2^{\mathrm{c}}$ & & \\
& Total & 9 & & \\
Ekperimen postest - & Negative ranks & $1^{\mathrm{d}}$ & 1.00 & 1.00 \\
kontrol postest & Positive ranks & $8^{\mathrm{e}}$ & 5.50 & 44.00 \\
& Ties & $0^{\mathrm{f}}$ & & \\
& Total & 9 & & \\
& & &
\end{tabular}

Berdasarkan data Tabel 15 yang merupakan deskriptif dari data yang diuji melalui Wilcoxon Signed test, yaitu data nilai pretest siswa dari kelompok kontrol dan juga kelompok eksperimen, dan data nilai postest siswa kelompok kontrol dan juga kelompok eksperimen. Berdasarkan data dalam Tabel 15 diketahui bahwa terdapat 4 siswa di kelompok eksperimen memiliki nilai pretest lebih kecil dari kelompok kontrol, terdapat 3 siswa di kelompok eksperimen yang mempunyai nilai pretest lebih tinggi dibandingkan kelompok kontrol, dan terdapat 2 siswa di kelompok eksperimen yang nilainya sama dengan kelompok kontrol.

Sementara itu, untuk nilai postest, hanya ada seorang siswa saja di kelompok eksperimen yang mendapatkan nilai postest lebih rendah dibandingkan siswa yang ada dalam kelompok kontrol, sedangkan 8 siswa lainnya mendapatkan nilai postest yang lebih tinggi dari siswa-siswa yang ada dalam kelompok kontrol. Hal tersebut berarti bahwa nilai pretest antara kelompok kontrol dengan eksperimen hampir sama saja, sedangkan nilai postest di kelompok eksperimen lebih besar dibandingkan kelompok kontrol, yang artinya bahwa model pembelajaran inkuiri terbimbing cukup memberikan hasil yang signifikan terhadap kemampuan siswa dalam dalam mengidentifikasi sumber-sumber energi yang ada di sekitar manusia.

Tabel 16. Hasil Output Akhir Uji Wilcoxon

\begin{tabular}{lcc}
\hline & Ekperimen Pretest - Kontrol & Ekperimen Postest - Kontrol \\
& Pretest & Postest \\
\hline$Z$ & $-.173^{\mathrm{b}}$ & $-2.554^{\mathrm{c}}$ \\
Asymp. Sig. (2-tailed) & .862 & .011 \\
\hline
\end{tabular}

a. Wilcoxon Signed Ranks Test

b. Based on positive ranks.

c. Based on negative ranks. 
Berdasarkan pada Tabel 16 hasil output uji Wilcoxon yang menunjukkan signifikan tidaknya perbedaan antara 2 sampel, yaitu data pretest kelompok kontrol serta kelompok eksperimen juga data postest kelompok kontrol dan eksperimen. Jika nilai Sig. $<0,05$ maka ada perbedaan yang signifikan di antara kedua data. Berdasarkan data dalam Tabel 16 dapat dilihat bahwa nilai Asymp. Sig. (2tailed) nilai pretest sebesar $0,862>0,05$, artinya tidak ada perbedaan yang mencolok antara nilai pretest di kelompok kontrol dengan kelompok eksperimen. Demikian juga dengan nilai Asymp. Sig. (2-tailed) dari data nilai postest sebesar 0,011<0,05 yang berarti terdapat perbedaan yang mencolok antara nilai postest di kelompok kontrol dengan kelompok eksperimen. Hal ini menunjukkan bahwa nilai postest dikedua kelompok nyaris sama atau tidak terdapat perbedaan, setelah salah satu kelompok mendapat sebuah perlakuan berupa pemberian pembelajaran dengan model inkuiri terbimbing.

Pada saat diberikan postest dengan soal yang sama, hasil pengujian menunjukkan bahwa nilai postest di kelompok eksperimen memiliki perbedaan yang signifikan dengan di kelompok kontrol, dimana nilai postest siswa di kelompok eksperimen jauh lebih baik dibandingkan kelompok kontrol. Hal ini menunjukkan model inkuiri terbimbing cukup efektif digunakan untuk memacu kemampuan siswa dalam mengidentifikasi sumber-sumber energi yang terdapat di sekitar manusia. Berdasarkan dari uji Wilcoxon secara keseluruhan, maka hipotesis penelitian kedua (H2) yang menyatakan bahwa: Terdapat pengaruh model inkuiri terbimbing terhadap kemampuan siswa dalam mengidentifikasi sumber-sumber energi yang terdapat di sekitar manusia, diterima karena hasil postest menunjukkan peningkatan yang signifikan dari hasil pretest, khususnya bagi siswa yang mendapatkan pembelajaran dengan menggunakan model inkuiri terbimbing.

Pembahasan

Pada penelitian ini menunjukkan hasil yaitu terdapat pengaruh model inkuiri terbimbing terhadap kemandirian belajar siswa. Hal tersebut juga sejalan dengan beberapa penelitian di jurnal maupun buku seperti pada penelitian yang dilakukan oleh Dewi, Dantes, dan Sadia (2013) yang menunjukkan hasil bahwa terdapat pengaruh model inkuiri terbimbing terhadap sikap ilmiah dan hasil belajar pada mata pelajaran IPA, dimana dalam penelitian tersebut mengambil subjek penelitian pada siswa kelas empat sekolah dasar dengan metode posttest-only control group design. Hasil dari penelitian tersebut adalah adanya pengaruh yang signifikan dari siswa yang menerima pembelajaran menggunakan model inkuiri terbimbing dengan siswa yang menerima pembelajaran dengan menggunakan metode konvensional.

Penelitian Munatri, Suyatna, dan Yulianti (2016) menunjukkan bahwa terdapat peningkatan hasil belajar siswa yang menggunakan model inkuiri terbimbing pada setiap siklus di sekolah. Penelitian yang dilakukam oleh Rahmaniar, Suhandi, dan Sari (2015) yang mendapatkan kesimpulan rerata hasil belajar pada pembelajaran fisika pada pembelajaran inkuiri terbimbing dengan menggunakan metode diskusi lebih tinggi dari pada menggunakan metode tanya jawab. Hal tersebut dikarenakan siswa yang mendapatkan pelajaran melalui model inkuiri terbimbing memiliki akses belajar yang lebih luas daripada metode konvensional tanya jawab. Pada metode konvensional tanya jawab sumber belajar siswa hanya terpusat pada guru, sedangkan pada model inkuiri terbimbing siswa dapat bebas mencari sumber belajar lain selain guru, seperti sumber-sumber melalui media internet, e-book, buku-buku atau literatur di perpustakaan, orang tua di rumah, dan lain sebagainya.

Hasil penelitian lain yang juga mendukung penelitian ini adalah pada penelitian yang dilakukan oleh Wahyuni, Hikmawati, dan Taufiq (2017) yang menyatakan bahwa terdapat pengaruh model pembelajaran inkuiri terbimbing dengan metode eksperimen terhadap hasil belajar fisika siswa kelas XI IPA SMA Negeri 2 Mataram tahun pelajaran 2016/2017. Dari penelitian tersebut, didapatkan hasil bahwa nilai rata-rata tes hasil belajar fisika kelas eksperimen yang menggunakan model pembelajaran inkuiri terbimbing dengan metode eksperimen lebih tinggi dibanding kelas kontrol yang menggunakan metode pembelajaran konvensional. Namun bukan berarti keberhasilan model inkuiri terbimbing ini tanpa kendala, beberapa tantangan dari model inkuiri terbimbing ini adalah dibutuhkannya ketelitian dan waktu penelitian yang tidak singkat untuk mendapatkan hasil penelitian yang sesuai. Fokus yang harus di perhatikan pada saat penelitian model inkuiri terbimbing 
ini adalah perlunya keseriusan guru dalam membimbing siswa untuk perihal praktikum, sehingga diharapkan seluruh siswa memahami instruksi yang di berikan oleh guru.

Penelitian terdahulu yang mendukung hasil dari penelitian ini adalah penelitian yang dilakukan oleh Muhtartinah (2015) yang menyebutkan bahwa terdapat lima aspek penilaian selama pembelajaran inkuiri terbimbing seperti kemampuan bertanya pada guru, menjawab pertanyaan dari guru, kemampuan bekerja sama dalam tim, berdiskusi, dan mengerjakan tugas yang di berikan oleh guru. Dari kelima indikator tersebut didapatkan peningkatan hasil rerata nilai siswa pada kelas eksperimen. Dalam penelitian yang dilakukan Muhtartinah (2015) didapatkan hasil yang menunjukkan bahwa terdapat pengaruh model inkuiri terbimbing yang signifikan terhadap kemampuan siswa dalam mengidentifikasikan sumber-sumber energi yang ada di kehidupan sehari-hari.

Pada hasil penelitian sebelumnya didapatkan hasil yang menunjukkan bahwa terdapat pengaruh model inkuiri terbimbing terhadap kemampuan siswa dalam mengidentifikasi sumbersumber energi yang ada di sekitar manusia. Hasil dari penelitian ini juga mendukung dari hasil penelitian-penelitian terdahulu yang dilakukan oleh Wulandari (2016) yang menunjukkan kesimpulan bahwa ketuntasan belajar siswa dan juga dari hasil presentase respon siswa terhadap pembelajaran inkuiri terbimbing yang telah mereka rasakan, respon tersebut dilihat dari beberapa indikator seperti: 1.) Kerja sama dalam kelompok sekelas; 2.) Rasa senang untuk belajar di kelas; 3.) Pemahaman atas materi mata pelajaran yang sedang di ajarkan oleh guru; 4.) Transfer ilmu pengetahuan dari sumber belajar yang lebih luas (tidak hanya dari guru); 5.) Ketertarikan dalam menggunakan media pembelajaran seperti LCD dan proyektor; dan 6.) Pola interaksi antara siswa dan guru yang lebih menyenangkan dan ingin menggunakan model inkuiri terbimbing lagi untuk materi berikutnya.

Penelitian yang juga mendukung hasil dari penelitian ini adalah penelitian yang dilakukan oleh A'yuna (2017) yang menyebutkan bahwa terdapat peningkatan nilai pretest dan posttest siswa pada kelas eksperimen pada kelas inkuiri terbimbing, sehingga kesimpulan dari penelitian tersebut adalah terdapat pengaruh model pembelajaran inkuiri terbimbing terhadap kemampuan siswa dalam mengidentifikasi sumber-sumber energi yang ada pada kehidupan sehari-hari.

\section{SIMPULAN}

Pada penelitian ini menunjukkan bahwa hasil analisis pretes adalah nilai pretest antara kelompok kontrol dengan kelompok eksperimen tidak menunjukkan perbedaan yang mencolok, ini dibuktikan dari hasil penilaian uji Asymp. Sig. (2-tailed) Wilcoxon yang mendapatkan nilai sebesar $0,862>0,05$, sedangkan nilai posttest antara kelompok kontrol dengan kelompok eksperimen menunjukkan adanya perbedaan yang signifikan, dimana nilai posttest kelompok eksperimen lebih tinggi dibandingkan kelompok kontrol. Hal tersebut dibuktikan dengan hasil penilaian Asymp. Sig. (2-tailed) Wilcoxon yang mendapatkan nilai sebesar $0,011<0,05$. Oleh karena itu, dapat disimpulkan bahwa model inkuiri terbimbing berpengaruh terhadap kemampuan siswa dalam mengidentifikasi sumber-sumber energi yang terdapat di sekitar manusia. Kesimpulan lainnya yang didapatkan yaitu: 1.) Terdapat pengaruh model inkuiri terbimbing terhadap kemandirian siswa, karena model inkuiri terbimbing lebih efektif dalam meningkatkan kemandirian belajar siswa; 2.) Terdapat pengaruh model inkuiri terbimbing terhadap kemampuan siswa dalam mengidentifikasi sumber-sumber energi yang ada di sekitar manusia, karena dengan menerapkan model inkuiri terbimbing siswa dapat lebih aktif dalam menjawab pertanyaan-pertanyaan materi; 3.) Peningkatan kemandirian belajar siswa hendaknya menggunakan model pembelajaran inkuiri terbimbing; dan 4.) Hasil penilaian atau evaluasi belajar siswa sudah tidak perlu lagi dengan cara membandingkan, karena tiap siswa memiliki keunikan dan karakteristik masing-masing.

\section{DAFTAR PUSTAKA}

Ariefianto, L. (2017). Homeschooling: Persepsi, latar belakang dan problematikanya (Studi kasus pada peserta didik di homeschooling Kabupaten Jember). Jurnal Edukasi, 4(2), 21-26. doi: https://doi.org/10.19184/jukasi.v4i2.5205 
92 - Jurnal Inovasi Teknologi Pendidikan

Arikunto, S. (2013). Prosedur penelitian: Suatu pendekatan praktik. Jakarta: Rineka Cipta.

A'yuna, Q. (2017). Pengaruh model pembelajaran inkuiri terbimbing terhadap kemampuan literasi sains siswa kelas X pada materi keanekaragaman hayati di SMA Negeri 2 Bandar Lampung (Unpublished doctoral dissertation). Institute Agama Islam Negeri (IAIN) Raden Intan, Indonesia.

Dewi, N. L., Dantes, N., \& Sadia, I. W. (2013). Pengaruh model pembelajaran inkuiri terbimbing terhadap sikap ilmiah dan hasil belajar IPA. E-Journal Program Pascasarjana Universitas Pendidikan Ganesha Jurusan Pendidikan Dasar, 3. Retrieved from https://media.neliti.com/media/publications/119287-ID-none.pdf

Ghozali, I. (2011). Aplikasi analisis multivariate dengan program SPSS. Semarang: Badan Penerbit Universitas Diponegoro.

Hair Jr, J. F., Matthews, L. M., Matthews, R. L., \& Sarstedt, M. (2017). PLS-SEM or CB-SEM: updated guidelines on which method to use. International Journal of Multivariate Data Analysis, 1(2), 107-123. doi: https://doi.org/10.1504/IJMDA.2017.087624

Munatri, S., Suyatna, A., \& Yulianti, D. (2016). Penerapan Model Pembelajaran Inkuiri Terbimbing Untuk Meningkatkan Hasil Belajar. Jurnal Teknologi Informasi Komunikasi Pendidikan, 4(1). Retrieved from http://jurnal.fkip.unila.ac.id/index.php/JT/article/view/10631/7261

Muhtartinah, Y. P. (2015). Pengaruh model pembelajaran inkuiri terbimbing (guided inquiry) dengan menggunakan metode eksperimen terhadap aktivitas dan hasil belajar IPA biologi siswa kelas VIII SMP Negeri 2 Maesan Bondowoso (Unpublished bachelor's thesis). Universitas Jember, Indonesia.

Prasetyo, B., \& Jannah, L. M. (2005). Metode penelitian kuantitatif: Teori dan aplikasi. Raja Grafindo Persada.

Rahmaniar, A., Suhandi, A., \& Sari, M. (2015, June). Ukuran pengaruh pendekatan interactive conceptual intruction pada pembelajaran fisika untuk meningkatkan pemahaman konsep usaha dan energi siswa SMA. Prosiding Simposium Nasional dan Pembelajaran Sains 2015 (SNIPS 2015), 261-264. Retrieved from http://portal.fmipa.itb.ac.id/snips2015/files/snips 2015 asri_rahmaniar_9ca66e42203e58d 4409750ebf1a60c51.pdf

Sugiyono, S. (2015). Statistik non-parametrik untuk penelitian. Bandung: Alfabeta.

Sukardi, S. (2003). Metodologi penelitian pendidikan kompetensi dan prakteknya. Jakarta: Bumi Aksara.

Susanti, A., Murtini, W., \& Harini, H. (2018). Development of web-based interactive multimedia for human resource management learning in vocational high schools. Jurnal Pendidikan Vokasi, 8(3), 300-312. doi: https://doi.org/10.21831/jpv.v8i3.20364

Wahyuni, R., Hikmawati, H., \& Taufik, M. (2017). Pengaruh model pembelajaran inkuiri terbimbing dengan metode eksperimen terhadap hasil belajar fisika siswa kelas XI IPA SMAN 2 Mataram tahun pelajaran 2016/2017. Jurnal Pendidikan Fisika dan Teknologi, 2(4), 164169. doi: http://dx.doi.org/10.29303/jpft.v2i4.308

Wibowo, E. P. (2016). Kompetensi guru dalam pemanfaatan sumber belajar by utilization di SDN Caturtunggal 6. E-Jurnal Skripsi Program Studi Teknologi Pendidikan, 5(5), 10-20. Retreived from http://journal.student.uny.ac.id/ojs/index.php/fiptp/article/view/2803

Wulandari, F. (2016). Penerapan model pembelajaran inkuiri terbimbing untuk meningkatkan hasil belajar IPA siswa sekolah dasar. PEDAGOGIA: Jurnal Pendidikan, 5(2), 267-278. doi: https://doi.org/10.21070/pedagogia.v5i2.259 